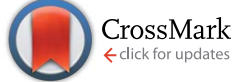

Cite this: RSC Adv., 2016, 6, 82890

Received 20th July 2016 Accepted 19th August 2016

DOI: $10.1039 / \mathrm{c} 6 \mathrm{ra} 18482 \mathrm{k}$

www.rsc.org/advances

\section{Mirror symmetry breaking in fluorinated bent-core mesogens $\dagger$}

\author{
Mohamed Alaasar, ${ }^{\text {*ab }}$ Marko Prehm ${ }^{\mathrm{a}}$ and Carsten Tschierske ${ }^{\text {*a }}$
}

Spontaneous chirality synchronization in the LC phases of achiral bent-core molecules, the so called dark conglomerate mesophases ( $\mathrm{DC}^{\left.\mathrm{F}^{*}\right]}$ phases), is a challenging task with significant importance for fundamental scientific research and potential applications. Here we report the synthesis and investigation of two new series of achiral bent-core mesogens derived from 4-bromoresorcinol and 4-chlororesorcinol with 2,3difluorinated azobenzene-based side arms. The self-assembly of these materials was characterized by DSC, polarizing microscopy, X-ray diffraction investigations (XRD) and electro-optical studies. Depending on the type of halogen substituent at the central resorcinol core and on the terminal alkyl chain length different types of mesophases were observed, where 4-bromoresocinol derived compounds predominately show helical nanocrystallite phases, (HNC phases), representing conglomerates of chiral domains $\left(\mathrm{DC}^{[*]}\right)$, whereas the related 4-chlororesorcinol based compounds form smectic $C$ phases with a polar domain structure $\left(\mathrm{SmC}_{\mathrm{S}} \mathrm{P}_{\mathrm{AR}}\right)$. Comparison with related compounds provides information about the influence of core fluorination on the mesophase behaviour and $D C^{[*]}$ phase formation, thus providing a step forward in uncovering the molecular design principles of LC materials capable of mirror symmetry breaking.

\section{Introduction}

Since the first report by Niori et al., ${ }^{1}$ about polar order in liquid crystalline (LC) phases formed by molecules with a non-linear bent shape, the so-called bent-core liquid crystals (BCLCs), extensive research has been done by several research groups on these fascinating materials. ${ }^{2}$ In recent years BCLCs have received great attention due to their remarkable and unique mesophases, especially the development of macroscopic polar order (ferroelectricity) and spontaneous mirror symmetry breaking, though the molecules themselves are achiral. This phenomenon is of general interest for fundamental soft matter science as well as for potential applications. Mirror symmetry breaking is a basic feature of living matter which was in the recent two decades also observed in some cases of LC phases. ${ }^{2-15}$ Dark conglomerate phases ( $\mathrm{DC}^{[*]}$ phases) represent one class of such spontaneously mirror symmetry broken mesophases exhibited by BCLCs.,16-19 They are optically isotropic and therefore characterized by completely dark appearance between crossed polarizers, whereas under slightly uncrossed polarizers chiral domains of opposite handedness can be observed. Related chiral domains were recently also observed in some nematic phases of dimesogens with odd-numbered spacers

${ }^{a}$ Institute of Chemistry, Martin Luther University Halle-Wittenberg, Kurt Mothes Str. 2, D-06120 Halle (Saale), Germany.E-mail: carsten.tschierske@chemie.uni-halle.de

${ }^{b}$ Department of Chemistry, Faculty of Science, Cairo University, Giza, Egypt. E-mail: malaasar@sci.cu.edu.eg

$\dagger$ Electronic supplementary information (ESI) available. See DOI: $10.1039 / \mathrm{c} 6 \mathrm{ra} 18482 \mathrm{k}$ (twist bend nematic phases $\left.\left(\mathrm{N}_{\mathrm{TB}}\right)\right),{ }^{9-11,20}$ in SmC phases formed by some azobenzene-based BCLCs, ${ }^{21}$ in bicontinuous cubic phases $^{22}$ and even in isotropic liquids formed by some polycatenar molecules. ${ }^{6,23,24}$ Also trimesogen can show $\mathrm{N}_{\mathrm{TB}}$ phases and soft crystalline $\mathrm{DC}^{[*]}$ phases. ${ }^{25}$ The $\mathrm{DC}^{[*]}$ phases of BCLCs are classified into three major types (Fig. 1), including the deformed smectic LC phases with sponge like structure, ${ }^{\mathbf{1 6}, 26-36}$ the helical nano-filament phases (HNF phases or B4 phases) where the molecules are arranged in arrays of helical nano-scale filaments, ${ }^{17,37-44}$ and the third type of $\mathrm{DC}^{[*]}$ phases being the helical nano-crystallites phases (HNC phases) which were recently observed for some azobenzene based BCLCs (see Scheme 1). ${ }^{\mathbf{4 5}-49}$

Herein we report two new series of BCLCs derived from 4bromoresorcinol and 4-chlororesorcinol central cores, respectively, ${ }^{50}$ with laterally 2,3-difluorinated azobenzene side arms (compounds $\mathbf{B r F}_{2} \boldsymbol{n}$ and $\mathbf{C l F}_{2} \boldsymbol{n}$, see Scheme 2). The 4-bromoresorcinol based compounds with medium alkyl chain lengths form helical nanocrystallite phases (HNC phase), representing

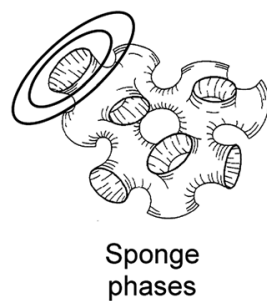

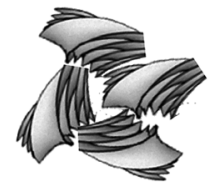

Helical nano-crystallite phases (HNC)

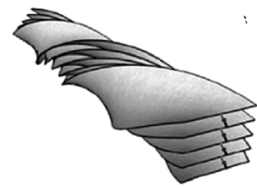

Helical nanofilament phases
Fig. 1 The three major types of dark conglomerate $\left(D C^{[*]}\right)$ phases. ${ }^{48}$ 


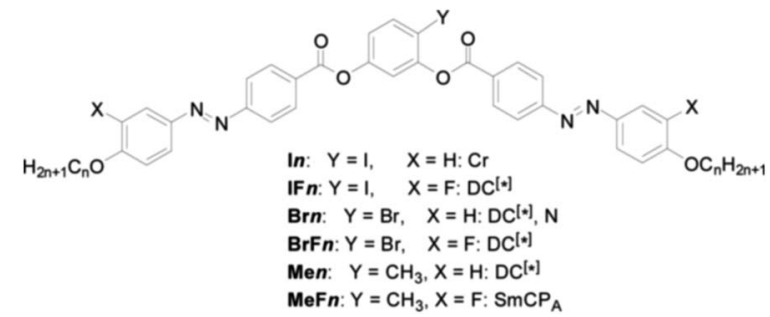

Scheme 1 Chemical structures of previously reported BCLCs with azobenzene-based wings with and without peripheral fluorine substitution. ${ }^{45-47,49}$ Abbreviations: $\mathrm{Cr}=$ crystalline solid; $\mathrm{DC}^{[*]}=$ dark conglomerate phases (HNC phases) composed of chiral domains with opposite handedness; $\mathrm{N}=$ nematic phase; $\mathrm{SmCP}_{\mathrm{A}}=$ antiferroelectric switching smectic phase.

optically isotropic soft crystalline phases forming conglomerates of chiral domains $\left(\mathrm{DC}^{[*]}\right.$ phases) which for the longest homologue are replaced by a smectic $\mathrm{C}$ phase composed of ferroelectric domains with antipolar correlation $\left(\mathrm{SmC}_{\mathrm{S}} \mathrm{P}_{\mathrm{AR}}\right) .^{51}$ The other series of compounds, which is derived from 4-chlororesorcinol, shows no HNC phases, but exclusively monotropic SmC phases which represent $\mathrm{SmC}_{\mathrm{S}} \mathrm{P}_{\mathrm{AR}}$ phases of a slightly different type. These compounds are compared with previously reported compounds without fluorine substitution or with a reduced number of fluorines in the side arms. ${ }^{47,49}$

\section{Experimental}

\subsection{Synthesis}

The synthesis of the target BCLCs $\mathbf{B r F}_{2} \boldsymbol{n}$ and $\mathbf{C l F}_{2} \boldsymbol{n}$ was carried out as shown in Scheme 2 by acylation reaction of the 4- halogenated resorcinol $\mathbf{V}$ with two equivalents of the benzoyl chlorides $\mathbf{I V} \boldsymbol{n}^{24}$ in the presence of triethylamine as base and pyridine as a catalyst. The final crude bent-core compounds $\mathbf{B r F}_{2} \boldsymbol{n}$ and $\mathbf{C l F}_{2} \boldsymbol{n}$ were purified by column chromatography using dichloromethane followed by recrystallization from ethanol/chloroform $(1: 1)$ mixture to yield the desired materials. Detailed procedures and the analytical data of the newly synthesised compounds $\mathbf{B r F}_{2} \boldsymbol{n}$ and $\mathbf{C l F}_{2} \boldsymbol{n}$ are reported in the ESI. $\uparrow$ All compounds are thermally stable as confirmed by the reproducibility of thermograms in several heating and cooling cycles.

\subsection{Methods}

The thermal behaviour of all synthesized compounds was studied by polarizing optical microscopy (POM) and differential scanning calorimetry (DSC). For polarizing microscopy a Mettler FP-82 HT hot stage and control unit in conjunction with a Nikon Optiphot-2 polarizing microscope was used. DSC-thermograms were recorded on a PerkinElmer DSC-7 with heating and cooling rates of $10 \mathrm{~K} \mathrm{~min}^{-1}$. Electro-optical switching characteristics were examined in 6 $\mu \mathrm{m}$ polyimide coated ITO cells (EHC Japan) using the triangular-wave method. ${ }^{52}$ XRD patterns were recorded with a 2D detector (Vantec-500, Bruker). Ni filtered and pin hole collimated $\mathrm{CuK}_{\alpha}$ radiation was used. The exposure time was $15 \mathrm{~min}$ and the sample to detector distance was 8.95 and $26.7 \mathrm{~cm}$ for small angle and wide angle scattering experiments, respectively. Alignment was attempted by slow cooling (rate: $1 \mathrm{~K} \mathrm{~min}^{-1}$ to $0.1 \mathrm{~K} \mathrm{~min}^{-1}$ ) of a small droplet on a glass plate.

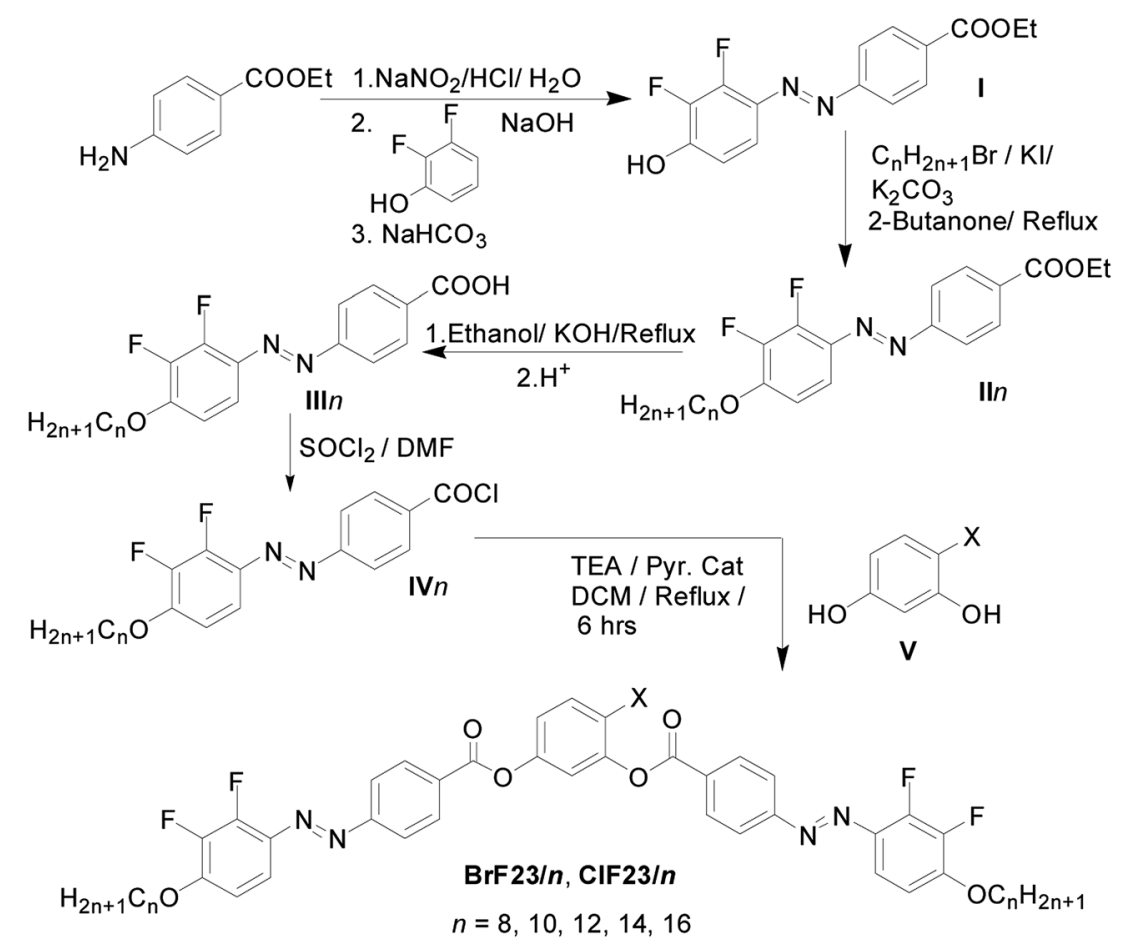

Scheme 2 Synthetic route to the bent-core mesogens under investigations. 


\section{Results and discussion}

\subsection{Dark conglomerate phases of compounds $\mathrm{BrF}_{2} n$ with $n$ $\leq 14$}

Depending on the terminal chain length, compounds $\mathbf{B r F}_{2} \boldsymbol{n}$ with a 4-bromoresorcinol central core form different types of mesophases. The shortest derivative $\mathbf{B r F}_{2} \mathbf{8}$ with $n=8$ forms a birefringent crystalline solid with melting point $T=104{ }^{\circ} \mathrm{C}$, whereas compounds $\mathbf{B r F}_{\mathbf{2}} \mathbf{1 0}-\mathbf{B r F}_{\mathbf{2}} \mathbf{1 4}$ with medium chain length exhibit monotropic highly viscous optically isotropic phases which, once formed, do not crystallize even after storage for one year at room temperature (see Table 1). Under crossed polarizers, these isotropic phases appear completely dark between crossed polarizers and on rotating the analyzer by a small angle $\left(\sim 10^{\circ}\right)$ out of the crossed position i.e. from the $90^{\circ}$ position with respect to the polarizer, uniform dark and bright domains appear, indicating the presence of chiral domains $\left(\mathrm{DC}^{\left[{ }^{*}\right]}\right.$ phases, see Fig. 2). That the distinct regions represent chiral domains with opposite handedness was confirmed by rotating the sample itself between crossed polarizers in different directions, where no change in the dark texture was observed.

The $\mathrm{DC}^{[*]}$-Iso transitions are associated with transition enthalpies values around $\Delta H \sim 21 \mathrm{~kJ} \mathrm{~mol}^{-1}$ in the cooling cycles (see Fig. 3 and Table 1), similar to their related analogues with only one fluorine substituent in each of the outer rings of the bent-core structure (compounds BrFn in Scheme 1). ${ }^{47}$ On heating the $\mathrm{DC}^{[*]}$ phases become instable and crystallize with formation of a birefringent crystalline phase. This crystallization is immediately followed by the melting of this crystalline phase, leading to the typical "double peak" in the heating scans (see Fig. 3). Similar to the $\mathrm{DC}^{[*]}$ phases exhibited by related BCLCs with two azobenzene wings (IFn, Brn, BrFn and Men, see Scheme 1), ${ }^{45-47,49}$ no current peak could be observed in these $\mathrm{DC}^{\left[{ }^{*}\right]}$ phases in electro-optical experiments. Moreover, no birefringence is induced in any of the $\mathrm{DC}^{[*]}$ phases under an applied triangular wave voltage up to $200 \mathrm{~V}_{\mathrm{pp}}$ in a $6 \mu \mathrm{m}$ ITO cell; this is typical for soft crystalline $\mathrm{DC}^{[*]}$ phases.

The XRD pattern of the $\mathrm{DC}^{[*]}$ phase exhibited by compound $\mathrm{BrF}_{2} \mathbf{1 0}$ at $50{ }^{\circ} \mathrm{C}$ as a representative example is shown in Fig. 4a and $\mathrm{b}$. A single strong scattering in the small angle region is observed. The $d$-value of $4.33 \mathrm{~nm}$ is between half of the molecular length and the full molecular length $\left(L_{\mathrm{mol}}=5.2 \mathrm{~nm}\right.$ in the most extended conformation with all-trans alkyl chains). This diffraction pattern is in line with a lamellar organization with $d=4.33$ $\mathrm{nm}$ where the molecules are organized in a single layer structure with the involved molecules tilted by a certain angle (the maximum tilt estimated from $d / L_{\text {mol }}=0.83$ is $\sim 33^{\circ}$ ) with respect to the layer normal. The relatively large difference between $d$ and $L_{\mathrm{mol}}$ is different from HNF phases having very small difference between the $d$-value and $L_{\text {mol }}{ }^{17,38}$ In the 2D patterns all scatterings form closed rings with uniform intensity distribution as a very typical feature of all $\mathrm{DC}^{\left[{ }^{*}\right]}$ phases. This is due to the randomized orientation of the nanocrystallites, leading to the optical isotropic properties, giving rise to the dark appearance between crossed polarizers (see Fig. $4 \mathrm{a}$ ). Fig. 4 b shows the $2 \theta$ scan over the diffraction pattern of $\mathbf{B r F}_{\mathbf{2}} \mathbf{1 0}$. Beside the strong layer reflections very weak and relatively broad scattering maxima are observed in the medium and wide angle region. This pattern distinguish this $\mathrm{DC}^{\left.\mathrm{F}^{*}\right]}$ phase from the fluid sponge-type $\mathrm{DC}^{[*]}$ phases, which exhibit only one completely diffuse wide angle scattering besides the layer reflection, ${ }^{26}$ as well as from the HNF phases (B4 phases) characterized by sharper and more intense wide angle scatterings. ${ }^{17,38}$ The results obtained for $\mathbf{B r F}_{\mathbf{2}} \mathbf{1 0}$ prove that the DC ${ }^{[*]}$ phases formed by compounds $\mathbf{B r F}_{2} \boldsymbol{n}$ belong to the helical nanocrystallite phases (HNC phases). Only the number, intensities and positions of the medium- and wide-angle scatterings are distinct, indicating that the fine structure of the local crystal lattice should be a bit different from the previously reported HNC phases of the related azobenzene derived apexhalogenated bent-core compounds. ${ }^{45,47,48}$ For example, Fig. 4c

Table 1 Phase transition temperatures $\left(T /{ }^{\circ} \mathrm{C}\right)$, mesophase types, and transition enthalpies $\left[\Delta H / \mathrm{kJ} \mathrm{mol}^{-1}\right]$ of compounds BrF $n^{a}$<smiles>CCCCCCCCCCOc1ccc(N=Nc2ccc(C(=O)Oc3ccc(Br)c(OC(=O)c4ccc(N=Nc5ccc(OCCC)c(F)c5F)cc4)c3)cc2)c(F)c1F</smiles>

\begin{tabular}{|c|c|c|c|}
\hline Compound & $n$ & Heating $T /{ }^{\circ} \mathrm{C}\left[\Delta H / \mathrm{kJ} \mathrm{mol}^{-1}\right]$ & Cooling $T /{ }^{\circ} \mathrm{C}\left[\Delta H / \mathrm{kJ} \mathrm{mol}^{-1}\right]$ \\
\hline $\mathrm{BrF}_{2} 8$ & 8 & $\mathrm{Cr}_{1} 96[6.6] \mathrm{Cr}_{2} 104$ [27.5] Iso & Iso $86[28.5] \mathrm{Cr}$ \\
\hline $\mathrm{BrF}_{2} 10$ & 10 & Cr $101[37.6]$ Iso & Iso $85[20.4] \mathrm{DC}^{[*]}$ \\
\hline $\mathrm{BrF}_{2} 14$ & 14 & $\mathrm{DC}^{[*]} 98[11.9]$ Cr 103 [7.8] Iso & Iso $92[21.6] \mathrm{DC}^{[*]}$ \\
\hline $\mathrm{BrF}_{2} 16$ & 16 & Cr 97 [26.5] Iso & Iso $96[6.2] \mathrm{SmC}_{\mathrm{s}} \mathrm{P}_{\mathrm{AR}} 85[20.2] \mathrm{Cr}$ \\
\hline
\end{tabular}

${ }^{a}$ The phase transition temperatures (peak temperatures) were taken from the second heating and second cooling scans at $10 \mathrm{~K}$ min ${ }^{-1}$; abbreviations: $\mathrm{Cr}=$ crystalline solid; $\mathrm{DC}^{[*]}=$ dark conglomerate phases (HNC phases) composed of chiral domains with opposite handedness; $\mathrm{SmC}_{\mathrm{S}} \mathrm{P}_{\mathrm{AR}}=$ polarization randomized smectic phase composed of $\mathrm{SmC}_{\mathrm{S}} \mathrm{P}_{\mathrm{F}}$ domains and showing two polarization current peaks; Iso $=$ isotropic liquid. 

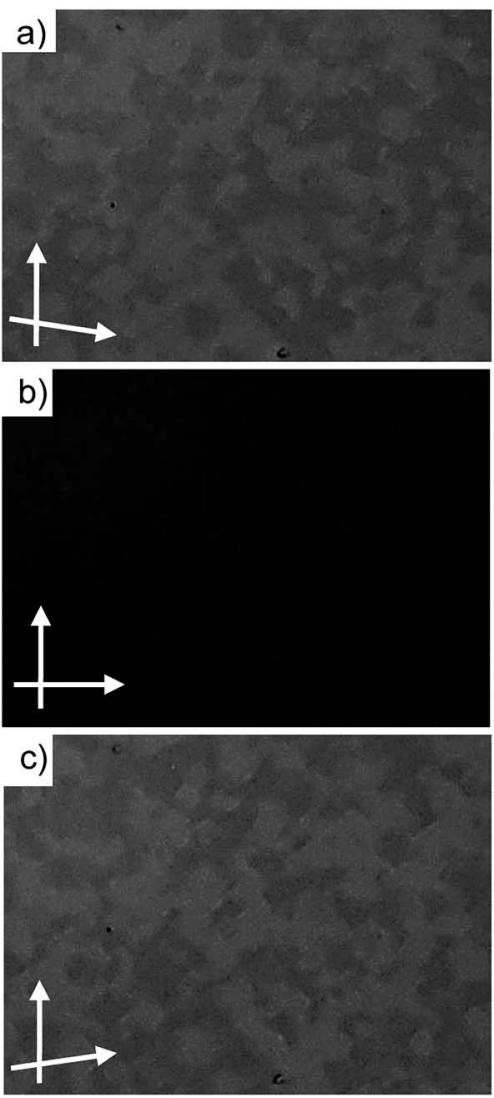

Fig. 2 Textures of the $\mathrm{DC}^{[*]}$ phase of compound $\mathrm{BrF}_{2} 12$ at $T=60^{\circ} \mathrm{C}$ : (b) under crossed polarizers; (a) after rotating the analyzer by $10^{\circ}$ from the crossed position with respect to the polarizer in clock-wise direction and (c) in anticlockwise direction, showing dark and bright domains, indicating the presence of areas with opposite chirality sense.

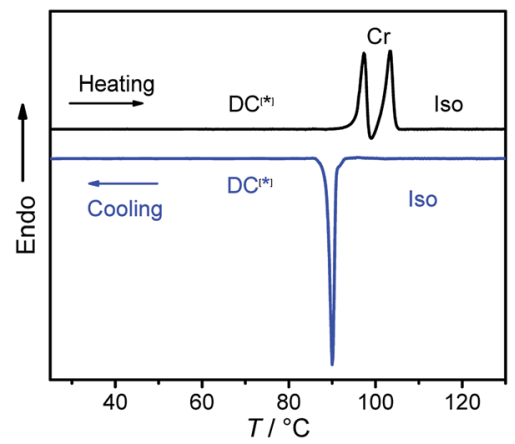

Fig. 3 DSC heating and cooling scans of $\mathrm{BrF}_{2} 12$ with a rate of $10 \mathrm{~K} \mathrm{~min}^{-1}$.

shows the $2 \theta$-scans of the $\mathrm{DC}^{[*]}$ phase of the related compound BrF12 with only one lateral fluorine substituent in each azobenzene wing and having the chain length $n=12$ (Scheme 1).

\subsection{SmC phase of the long chain compound $\mathrm{BrF}_{2} 16$}

The optically isotropic $\mathrm{DC}^{[*]}$ phase is completely removed for the longest derivative in the series $\mathbf{B r F}_{2} \boldsymbol{n}$ with $n=16$. On cooling $\mathbf{B r F}_{\mathbf{2}} \mathbf{1 6}$ from the isotropic liquid state a birefringent schlieren a)

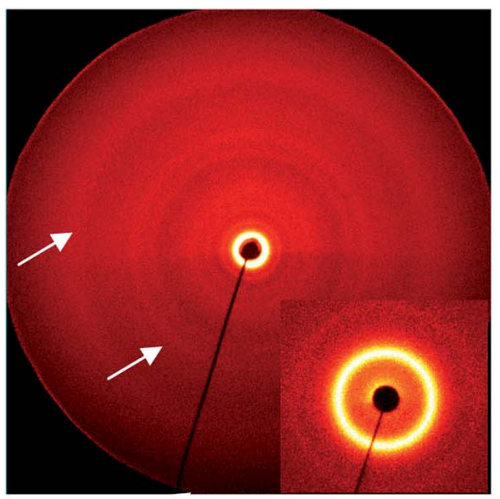

b)

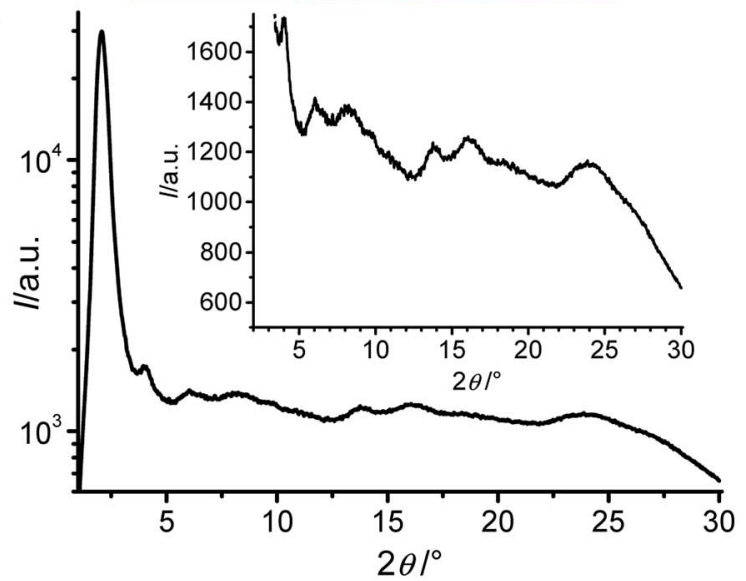

c)

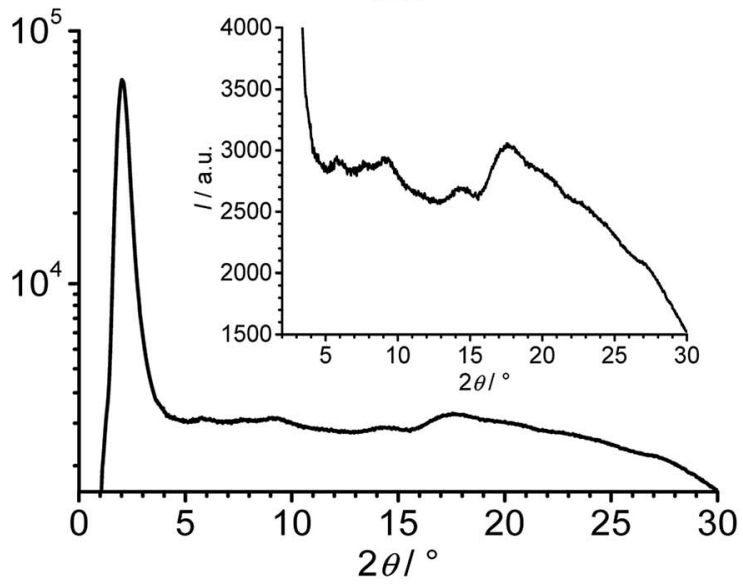

Fig. 4 (a) $2 \mathrm{D} X R \mathrm{R}$ pattern of the $\mathrm{DC}^{[*]}$ phase of $\mathrm{BrF}_{2} 10$ at $T=50^{\circ} \mathrm{C}$, the inset shows the small angle region; $2 \theta$-scans over this XRD pattern of the $\mathrm{DC}^{[*]}$ phase for (b) compound $\mathrm{BrF}_{2} 10$ at $T=50{ }^{\circ} \mathrm{C}$ and (c) compound BrF12 at $T=90^{\circ} \mathrm{C}$. $^{47}$

texture is observed below $T=96{ }^{\circ} \mathrm{C}$ in a homeotropic cell (Fig. 5a) and a fan texture is observed in a planar cell where the dark extinctions are inclined by an angle of about $28^{\circ}$, indicating a synclinic tilted smectic phase $\left(\mathrm{SmC}_{\mathrm{s}}\right.$ phase, see Fig. $\left.5 \mathrm{~b}\right)$. XRD investigation of this phase was not possible due to the rapid crystallization of the monotropic phase. In electro-optical investigations two polarization current peaks in each half period of an applied triangular wave voltage were observed (Fig. 5c and d). The two polarization peaks are weak and widely separated at the Iso- $\mathrm{SmC}_{\mathrm{s}}$ transition, growing in intensity and coming a bit closer to each other on further cooling, reaching 

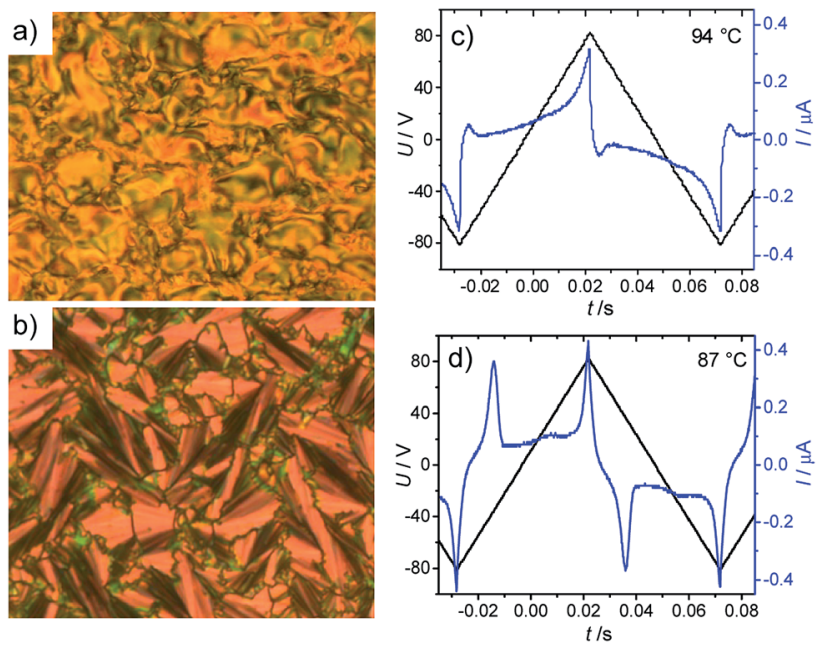

Fig. 5 Textures and polarization current response curve of the $\mathrm{SmC}_{\mathrm{s}} \mathrm{P}_{\mathrm{AR}}$ phase of compound $\mathrm{BrF}_{2} 16$ : textures as observed at $T=$ $93^{\circ} \mathrm{C}$ (a) in a homeotropic cell; (b) in a $6 \mu \mathrm{m}$ coated ITO cell with planar alignment; (c) and (d) switching current response curves in the same ITO cell as recorded under a triangular wave voltage $160 \mathrm{~V}_{\mathrm{pp}}(10 \mathrm{~Hz}, 5$ $\mathrm{k} \Omega$ ) at the indicated temperatures.

a polarization values $P=290 \mathrm{nC} \mathrm{cm}^{-2}$. The mode of appearance of the polarization peaks, their shape and the relatively small polarization values are typical for $\mathrm{SmC}_{\mathrm{S}} \mathrm{P}_{\mathrm{AR}}$ phases with randomized polar order, described in detail for 4-cyanoresorciol based BCLCs. ${ }^{51}$ Therefore, the LC phase of compound $\mathbf{B r F}_{\mathbf{2}} \mathbf{1 6}$ is assigned as $\mathrm{SmC}_{\mathrm{s}} \mathrm{P}_{\mathrm{AR}}$ phase. In this smectic phase ferroelectric domains with synclinic and antipolar correlation form a field induced $\mathrm{SmC}_{\mathrm{S}} \mathrm{P}_{\mathrm{F}}$ state which relaxes at reduced voltage back to a macroscopically antipolar structure. The position of the dark extinctions does not change, indicating the relaxation and switching take place by rotation around the molecular long axis (see Fig. S11†).

\subsection{Investigation of mixtures of compounds $\mathrm{BrF}_{2} n$ with 5-} CB

It is well known that the two different types of soft crystalline $\mathrm{DC}^{[*]}$ phases (HNF and HNC) behave differently upon mixing with $4^{\prime}$ - $n$-pentyl-4-cyanobiphenyl (5-CB). The chirality of HNF phases can be retained even at high dilution with a nematic LC host $(>95 \%),{ }^{53}$ while the HNC phases can be diluted only by a small amount (to $\sim 50 \%$ ) of a nematic LC (5-CB) without loss of the $\mathrm{DC}^{\left[{ }^{*}\right]}$ phase and chirality. ${ }^{45-47}$ The mixtures of selected compounds $\mathbf{B r F}_{2} \boldsymbol{n}$ with 5-CB were investigated and compared with the results obtained for their related monofluorinated analogues BrFn (see Table 2).

The DC ${ }^{[*]}$ phase of the pure compound $\mathbf{B r F}_{2} \mathbf{1 0}$ is removed in its 1:1 mixture with $5 \mathrm{CB}$ and a direct transition from the crystalline state to the isotropic liquid takes place at $68{ }^{\circ} \mathrm{C}$ on heating (Table 2). On cooling the same mixture from the isotropic liquid state a monotropic nematic phase is formed which crystallizes at $T \sim 39{ }^{\circ} \mathrm{C}$ without the formation of $\mathrm{DC}^{[*]}$ phase. The next two homologues $\mathbf{B r F}_{2} \mathbf{1 2}$ and $\mathbf{B r F}_{\mathbf{2}} \mathbf{1 4}$ behave differently; $\mathrm{DC}^{[*]}$ phases are formed in their $1: 1$ mixtures with
Table 2 Phase transition temperatures and mesophase types of $1: 1$ mixtures of $5-\mathrm{CB}$ and compounds BrF10-BrF14 and comparison with related 4-bromoresorcinol derivatives BrF10-BrF14 ${ }^{a 46}$

\begin{tabular}{lll}
\hline Mixture & Heating $T /{ }^{\circ} \mathrm{C}$ & Cooling $T /{ }^{\circ} \mathrm{C}$ \\
\hline BrF $_{2} 10+5-\mathrm{CB}$ & Cr 68 Iso & Iso $47 \mathrm{~N} 39 \mathrm{Cr}$ \\
$\mathrm{BrF}_{2} 12+5-\mathrm{CB}$ & $\mathrm{DC}^{[*]} 60$ Iso & Iso $56 \mathrm{DC}^{[*]}$ \\
$\mathrm{BrF}_{2} 14+5-\mathrm{CB}$ & $\mathrm{DC}^{[*]} 58$ Iso & Iso $54 \mathrm{DC}^{[*]}$ \\
$\mathrm{BrF10}^{[*}$-CB & $\mathrm{Cr} 54$ Iso & Iso $42 \mathrm{~N} 33 \mathrm{Cr}$ \\
BrF12 $+5-\mathrm{CB}$ & $\mathrm{Cr}^{[*]} 40 \mathrm{DC}^{[*]} 55 \mathrm{Iso}$ & Iso $53 \mathrm{DC}^{[*]} 38 \mathrm{Cr}{ }^{[*]}$ \\
BrF14 $+5-\mathrm{CB}$ & $\mathrm{Cr} 38 \mathrm{DC}^{[*]} 64$ Iso & Iso $46 \mathrm{DC}^{[*]} 35 \mathrm{Cr}$
\end{tabular}

${ }^{a}$ Transition temperatures were taken from the observed textures using the polarized optical microscopy; abbreviations: $\mathrm{N}=$ nematic phase; $\mathrm{Cr}^{\left[{ }^{*}\right]}=$ crystalline phase composed of a conglomerate of chiral domains; for other abbreviations please see Table 1.
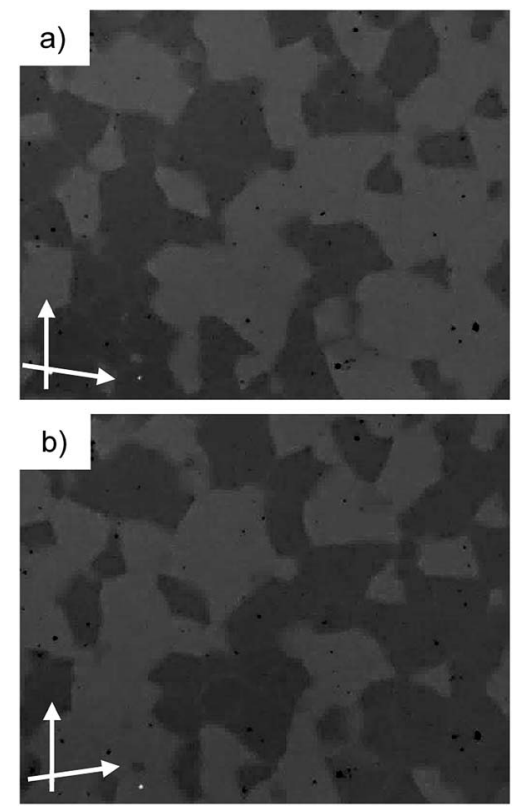

Fig. 6 Textures of the $\mathrm{DC}^{[*]}$ phase of $1: 1$ mixture of compound $\mathrm{BrF}_{2} 14$ with $5 \mathrm{CB}$ at $T=45^{\circ} \mathrm{C}$ : (a) after rotating one polarizer by $10^{\circ}$ from the crossed position in clock-wise direction and (b) in anticlockwise direction, showing dark and bright domains, indicating the presence of areas with opposite chirality sense.

5CB as room temperature mesophases and no crystallization takes place either on heating or cooling (see Fig. 6). Similar to the other HNC phases, only a limited amount of 5-CB can be mixed into the HNC phase of $\mathbf{B r F}_{2} \boldsymbol{n}$ and any further increase of the amount of 5 -CB removes the $\mathrm{DC}^{[*]}$ phases. Comparing the results obtained for $\mathbf{B r F}_{2} \boldsymbol{n}$ compounds with their monofluorinated analogues (compounds BrFn, see Table 2) ${ }^{47}$ indicate that both types of compounds behave similarly in their mixed systems, which further confirms the similarity of the HNC phases exhibited by the azobenzene based bent-core mesogens.

\subsection{Compounds $\mathrm{ClF}_{2} n$ with chlorine at the apex}

The effect of replacing bromine by a smaller chlorine on the mesophase type has been investigated with the 4- 
chlororesorcinol derived compounds $\mathbf{C l F}_{2} \boldsymbol{n}$ (see Table 3 for data and Fig. 7 for DSC traces for $\mathbf{C l F}_{2} \mathbf{1 4}$ ). Unlike series $\mathbf{B r F}_{2} \boldsymbol{n}$, compounds $\mathbf{C l F}_{2} \boldsymbol{n}$ do not show any $\mathrm{DC}^{[*]}$ phase; instead they form monotropic smectic $\mathrm{C}$ phases. On cooling the shorter homologues with $n=8$ and 10 from the isotropic liquid state a birefringent SmC phase is observed at the same temperature $T$ $=86{ }^{\circ} \mathrm{C}$ for both derivatives. The investigations of these SmC phases was not possible due to the rapid crystallization starting directly after the appearance of the SmC and for the same reason the value of transition enthalpy for the Iso-SmC transition cannot be separated from that of SmC-Cr transition. For the next homologues with $n \geq 12$ the SmC phases are formed in a sufficient temperature range enabling electro-optical investigations. The temperature range of the SmC phases in the series $\mathbf{C l F}_{\mathbf{2}} \mathbf{1 2}-\mathbf{C l F}_{\mathbf{2}} \mathbf{1 6}$ is increasing with increasing the chain length (see Table 3). Fig. 8a and b shows the textures observed for the SmC phase of compound $\mathbf{C l F}_{\mathbf{2}} \mathbf{1 6}$ upon cooling from the isotropic liquid state, where a birefringent schlieren texture is observed in a homeotropic cell (Fig. 8a). A broken fan texture with the dark extinctions inclined by an angle of $26^{\circ}$, indicating a synclinic tilted smectic phase $\left(\mathrm{SmC}_{\mathrm{s}}\right.$ phase) is observed in a planar cell (Fig. 8b).

Under an applied triangular wave voltage of $160 \mathrm{~V}_{\mathrm{pp}}$ in a 6 $\mu \mathrm{m}$ ITO cell two broad polarization peaks per half period of the applied voltage appears in the SmC phase of all investigated $\mathbf{C l F}_{2} \boldsymbol{n}$ compounds with $n=12-16$ with a polarization value $P \sim$ $100 \mathrm{nC} \mathrm{cm}{ }^{-2}$ (see Fig. 8c for $\mathbf{C l F}_{\mathbf{2}} \mathbf{1 6}$ ). Based on the textures and the shape of the polarization curves, the SmC phases exhibited by these materials are assigned as $\mathrm{SmC}_{\mathrm{S}} \mathrm{P}_{\mathrm{AR}}$ phases, but the shape and the polarization values are very distinct from that of the analogous bromine substituted compound $\mathbf{B r F}_{\mathbf{2}} \mathbf{1 6}$. The broad diffuse shape of the polarization current peaks is similar to that observed for previously reported $\mathrm{SmAP}_{\mathrm{AR}}$ phase showing Langevin-type switching. ${ }^{54}$ Therefore, we conclude that the switching of the chlorine substituted compounds is also typically Langevin type, ${ }^{55}$ meaning that small polar

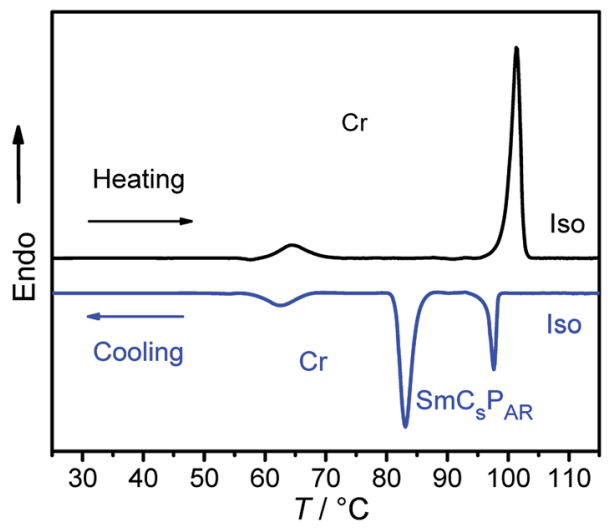

Fig. 7 DSC heating and cooling scans of $\mathrm{ClF}_{2} 14$ with a rate of $10 \mathrm{~K}$ $\min ^{-1}$.

domains grow under the electric field and then can be switched between two polar states. This means that the polar domains in the SmC phase of $\mathbf{C l F}_{\mathbf{2}} \mathbf{1 6}$ might have a broader size distribution than those observed in the $\mathrm{SmC}_{\mathrm{S}} \mathrm{P}_{\mathrm{AR}}$ phase of $\mathbf{B r F}_{2} \mathbf{1 6}$ and grow to larger domains under the applied field. There is a larger threshold voltage for polar switching of $\mathbf{B r F}_{2} \mathbf{1 6}$ compared to $\mathbf{C l F}_{\mathbf{2}} \mathbf{1 6}$ though the magnitude of polarization is higher ( 280 vs. $100 \mathrm{nC} \mathrm{cm}^{-2}$ ). Probably there is larger polarization in the ferroelectric domains of $\mathbf{B r F}_{2} \mathbf{1 6}$ but also a stronger antipolar correlation between these domains. It appears that bromine substitution favours polar packing compared to the smaller chlorine, though it could be expected that the bend of the bromine substituted compound might be a bit smaller than that of the chlorine substituted, ${ }^{50 a}$ and additionally, the bulkier bromine is expected to reduce the core packing density for steric reasons. This effect might possibly be attributed to the higher polarizability of bromine and the $\mathrm{C}-\mathrm{Br}$ bond.

Table 3 Phase transition temperatures $\left(T /{ }^{\circ} \mathrm{C}\right)$, mesophase types, and transition enthalpies $\left[\Delta H / \mathrm{kJ} \mathrm{mol}^{-1}\right]$ of compounds $\mathrm{ClF}_{2} n^{a}$

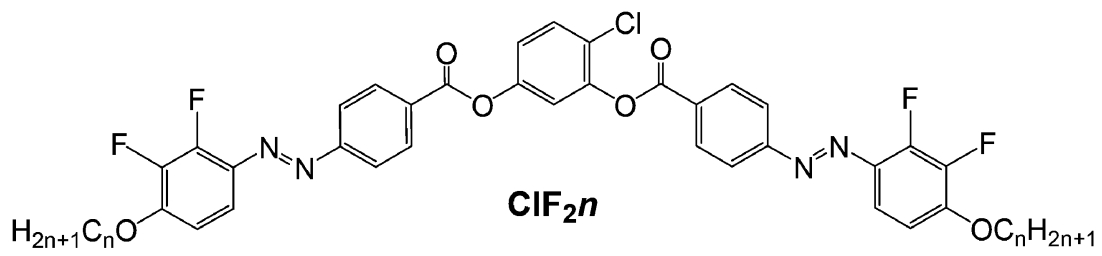

\begin{tabular}{|c|c|c|c|}
\hline Compound & $n$ & Heating $T /{ }^{\circ} \mathrm{C}\left[\Delta H / \mathrm{kJ} \mathrm{mol}^{-1}\right]$ & Cooling $T /{ }^{\circ} \mathrm{C}\left[\Delta H / \mathrm{kJ} \mathrm{mol}^{-1}\right]$ \\
\hline $\mathrm{ClF}_{2} 8$ & 8 & Cr 98 [33.1] Iso & Iso $86[30.7] \mathrm{Cr}+\mathrm{SmC}_{x}{ }^{b}$ \\
\hline $\mathrm{ClF}_{2} 10$ & 10 & Cr 101 [35.9] Iso & Iso $86[35.7] \mathrm{Cr}+\mathrm{SmC}_{x}{ }^{b}$ \\
\hline $\mathrm{ClF}_{2} 14$ & 14 & Cr 101 [37.9] Iso & Iso $98[8.6] \mathrm{SmC}_{\mathrm{S}} \mathrm{P}_{\mathrm{AR}} 83[27.5] \mathrm{Cr}$ \\
\hline $\mathrm{ClF}_{2} 16$ & 16 & Cr 105 [35.7] Iso & Iso $100[7.5] \mathrm{SmC}_{\mathrm{s}} \mathrm{P}_{\mathrm{AR}} 75[37.2] \mathrm{Cr}$ \\
\hline
\end{tabular}

${ }^{a}$ The phase transition temperatures were measured as mentioned in Table $1 .{ }^{b}$ The value of Iso-SmC transition enthalpy cannot be separated from SmC-Cr transition value. Abbreviations: $\mathrm{SmC}_{x}=$ smectic C phase with unknown polar structure, most likely also representing $\mathrm{SmC}_{\mathrm{S}} \mathrm{P}_{\mathrm{AR}}$ phases; for other abbreviations see Table 1. 

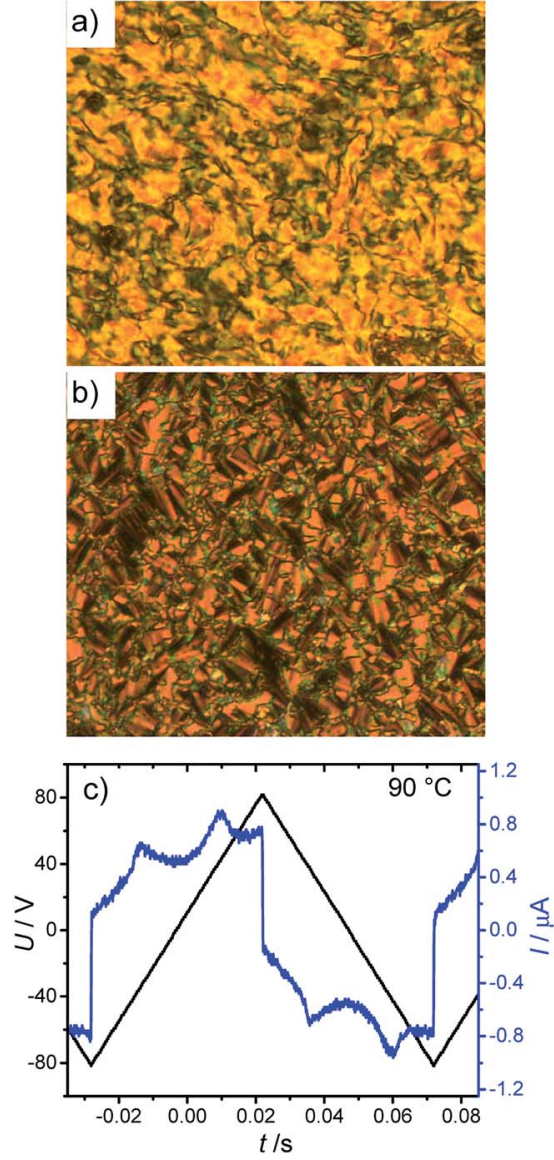

Fig. 8 Textures and polarization current response curve of the $\mathrm{SmC}_{\mathrm{S}} \mathrm{P}_{\mathrm{AR}}$ phase of compound $\mathrm{ClF}_{2} 16$ at $T=90{ }^{\circ} \mathrm{C}$ : (a) texture as observed in a homeotropic cell; (b) texture observed in a $6 \mu \mathrm{m}$ coated ITO cell with planar alignment and (c) switching current response curve in the same ITO cell as recorded under a triangular wave voltage $160 \mathrm{~V}_{\mathrm{pp}}(10 \mathrm{~Hz}, 5 \mathrm{k} \Omega)$.

\subsection{Comparison with related compounds}

Table 4 shows a comparison between azobenzene derived BCLCs with 4-bromoresorcinol and 4-chlororesorcinol cores and $n=12$ chain length, but with different number of peripheral fluorine substituents. Before discussing the effect of fluorine substitution, it is mentioned here that the larger bromine atom $\left(\mathrm{cv} \sim 33 \mathrm{~nm}^{3} \text {, crystal volumes } \mathrm{cv} \text { of Immirzi }\right)^{56}$ in the 4 position at the resorcinol core favours the formation of HNC phase in all cases compared to the smaller chlorine (cv $\sim 27$ $\left.\mathrm{nm}^{3}\right),{ }^{56}$ indicating that the size of the substituent at the apex and the degree of molecular twist induced by this substituent are important for layer distortion and chirality synchronization required for $\mathrm{DC}^{\left[{ }^{*}\right]}$ phase formation. ${ }^{47}$ For the BCLCs with 4 bromoresorcinol central core, peripheral fluorination removes the nematic phase and stabilizes the HNC phase, most probably by increasing the attractive $\pi-\pi$ interactions by reduction of the electron density of the aromatics. However, inserting an additional fluorine atom in the meta position with respect to the terminal alkyl chain (compound $\mathbf{B r F}_{\mathbf{2}} \mathbf{1 2}$ ) reduces the HNC phase stability (reduced transition temperature Iso-DC) and favours crystallization. Reduction of HNC phase stability is probably due to the steric effect of the additional fluorine, reducing the packing density. The increased melting points are attributed to the improved $\pi-\pi$-stacking ability caused by the further reduction of the electron density by the additional electron withdrawing fluorine.

In the case of the compounds derived from 4-chlororesorcinol the core fluorination removes the nematic phase, too, but in this case it leads first to a macroscopically polar $\left(\operatorname{SmC}_{\mathrm{a}} \mathrm{P}_{\mathrm{A}}\right)$ and then, after addition of the next fluorine, to a locally polar tilted smectic phase $\left(\mathrm{SmC}_{\mathrm{s}} \mathrm{P}_{\mathrm{AR}}\right.$, see Table 4$)$. The mesophase stability of the LC phases is apparently not affected by fluorination, but the introduction of the second fluorine in $m$-position removes the long range polar order achieved for the monofluorinated compound (two sharp polarization peaks, $P_{\mathrm{s}}$

Table 4 Phase transition temperatures $\left(T /{ }^{\circ} \mathrm{C}\right)$ and mesophase types for different types of 4-bromoresorcinol and 4-chlororesorcinol derived $B C L C s$ with azobenzene wings and the effect of peripheral $F$-atoms $\left(Y, Y^{\prime}=H, F\right)^{a}$<smiles>[Y]c1c(N=Nc2ccc(OC(=O)c3ccc(N=Nc4ccc(OCCCCC)c([Y])c4[Y])cc3)cc2)ccc(OCCC)c1[Y]</smiles>

\begin{tabular}{|c|c|c|c|c|c|}
\hline Comp. & $\mathrm{x}$ & $\mathrm{Y}$ & $\mathrm{Y}^{\prime}$ & $T /{ }^{\circ} \mathrm{C}$ & Ref \\
\hline Br12 & $\mathrm{Br}$ & $\mathrm{H}$ & $\mathrm{H}$ & $\mathrm{DC}^{[*]} 93$ (N 83) Iso & 49 \\
\hline BrF12 & $\mathrm{Br}$ & $\mathrm{F}$ & $\mathrm{H}$ & $\mathrm{DC}^{[*]} 106$ Iso & 47 \\
\hline $\mathrm{BrF}_{2} 12$ & $\mathrm{Br}$ & $\mathrm{F}$ & $\mathrm{F}$ & $\mathrm{Cr}_{1} 97 \mathrm{Cr}_{2} 103\left(\mathrm{DC}^{[*]}\right.$ 90) Iso & \\
\hline Cl12 & $\mathrm{Cl}$ & $\mathrm{H}$ & $\mathrm{H}$ & $\mathrm{Cr}_{1} 90 \mathrm{Cr}_{2} 103$ (N 97) Iso & 49 \\
\hline ClF12 & $\mathrm{Cl}$ & $\mathrm{F}$ & $\mathrm{H}$ & Cr $115\left(\mathrm{SmC}_{\mathrm{a}} \mathrm{P}_{\mathrm{A}}\right.$ 97) Iso & 47 \\
\hline $\mathrm{ClF}_{2} \mathbf{1 2}$ & $\mathrm{Cl}$ & $\mathrm{F}$ & $\mathrm{F}$ & Cr $101\left(\mathrm{SmC}_{\mathrm{S}} \mathrm{P}_{\mathrm{AR}}\right.$ 97) Iso & \\
\hline
\end{tabular}

${ }^{a}$ Abbreviations: $\mathrm{N}=$ nematic phase; $\mathrm{SmC}_{\mathrm{a}} \mathrm{P}_{\mathrm{A}}=$ anticlinic antiferrelectric switching SmC phase (B2 phase); for other abbreviations see Table 1 . 
$\sim 500 \mathrm{nC} \mathrm{cm}^{-2}$, see Fig. S11† in ref. 47) and replaces this by a local polar domain structure (two diffuse polarization peaks, $P_{\mathrm{s}} \sim 100 \mathrm{nC} \mathrm{cm}^{-2}$, Fig. 8c). Simultaneously the additional $\mathrm{F}$ substituents change the tilt correlation in the smectic phase from anticlinic in $\mathbf{C l F 1 2}$ to synclinic in $\mathbf{C l F}_{\mathbf{2}} \mathbf{1 2}$ and the switching process from rotation on the tilt-cone for ClF12 (Fig. S10 $†$ in ref. 47) to a reorganization around the long axis in the case of $\mathbf{C l F}_{2} \boldsymbol{n}$ (Fig. S11†). This is most probably an effect of the reduced packing density, favoured by the increased bulkiness of the rodlike wings with two adjacent fluorines in each azobenzene wing. Overall, there seems to be a delicate balance of the influence of the two competing effects. It appears that the packing density is increased most efficiently by the electron accepting 3-fluorination adjacent to the 4-alkyloxy chain, whereas 2 -fluorination in meta position to the alkyloxy chain contributes more to the unfavourable steric effect of fluorine, thus reducing the packing density. Besides the steric and electronic effects of fluorination, fluorine substitution can also have an effect on the conformation of the $\mathrm{Ar}-\mathrm{O}-\mathrm{CH}_{2}$ linkage by influencing orbital interactions $^{57}$ and by strengthening weak intra-and intermolecular hydrogen bonding involving $\mathrm{C}-\mathrm{H}$ bonds,${ }^{58}$ thus supporting the twisting of the molecules and the formation of $\mathrm{DC}^{[*]}$ phases.

\section{Summary and conclusions}

Two series of new bent-core liquid crystalline materials combining 4-bromoresorcinol or 4-chlororesorcinol cores with two 2,3-difluorinated and 4-alkoxy substituted azobenzene side arms have been synthesized and investigated. Depending on the size of the halogen atom in 4-position of the central bent core unit ( $\mathrm{Cl} v s$. $\mathrm{Br}$ ) and on the length of the terminal alkyl chains different types of mesophases were observed. It was found that the majority of 4-bromoresorcinol derived compounds $(n=10-14)$ form HNC-type $\mathrm{DC}^{[*]}$ phases which are replaced by a $\mathrm{SmC}_{\mathrm{S}} \mathrm{P}_{\mathrm{AR}}$ phase upon chain elongation $(n=16)$. For the 4-chlororesorcinol derivatives only SmC phases, but no $\mathrm{DC}^{[*]}$ phases were observed. The investigated SmC phases represent $\mathrm{SmC}_{\mathrm{S}} \mathrm{P}_{\mathrm{AR}}$ type polar domain phases. The $\mathrm{SmC}_{\mathrm{S}} \mathrm{P}_{\mathrm{AR}}$ phase of the chlorine substituted compound is distinct from that of the related bromine derivative by the significantly broader polarization peaks and the smaller polarization values, indicating a Langevin-type switching (field-induced growth of the polar domains) for the chlorinated compound and a more superparaelectric type of switching $^{59}$ (fusion of already existing polar domains) for the brominated compound. The $\mathrm{DC}^{[*]}$ phases exhibited by these materials represent helical nano-crystallites phases (HNC) but with a different local structure if compared with the HNC phases of the related azobenzene compound without peripheral fluorine or with only one fluorine. ${ }^{4749}$ Though, core fluorination can favour HNC phase formation and modifies the precise phase structure, it cannot induce DC phases if the core unit would not also support its formation. It also cannot fundamentally change the structure of the $\mathrm{DC}^{[*]}$ phase to HNF or fluid DC phases. Introduction of the first fluorine adjacent to the alkoxy chains obviously favors layer formation and $\mathrm{DC}^{\left[{ }^{*}\right]}$ phase formation (removal of $\mathrm{N}$ phases) and development of polar order, most probably by increasing the attractive $\pi-\pi$ interactions by reduction of the electron density of the aromatics. The second fluorine appears to reduce the $\mathrm{DC}^{[*]}$ phase stability a bit and appears to reduce the coherence length of local polarization, probably due to its steric effect, reducing the packing density a bit. Thus fluorination is a tool for tailoring HNC phase ranges and the fine structure of the HNC phases. Future work will be devoted to a more detailed analysis of the HNC phases by imaging methods and the investigation of the effects of photoisomerization of the azobenzene units incorporated in the molecular structure of these BCLCs by polarized and nonpolarized light. This could lead to additional possibilities for phase modulation and chirality modulation, which could result in potentially useful applications.

\section{Acknowledgements}

The work was supported by the DFG (Grant Ts 39/24-1). M. Alaasar is grateful to the Alexander von Humboldt Foundation for the research fellowship at the Martin-Luther University Halle-Wittenberg, Germany.

\section{References}

1 T. Niori, T. Sekine, J. Watanabe, T. Furukawa and H. Takezoe, J. Mater. Chem., 1996, 6, 1231-1233.

2 (a) R. A. Reddy and C. Tschierske, J. Mater. Chem., 2006, 16, 907-961; (b) H. Takezoe and Y. Takanishi, Jpn. J. Appl. Phys., Part 1, 2006, 45, 597-625; (c) A. Eremin and A. Jákli, Soft Matter, 2013, 9, 615-637; (d) J. Etxebarria and M. B. Ros, J. Mater. Chem., 2008, 18, 2919-2926; (e) M. Alaasar, Liq. Cryst., 2016, DOI: 10.1080/02678292.2016.1175676.

3 C. Tschierske, Nanoscale stereochemistry in liquid crystals, in Chirality at the nanoscale, ed. D. B. Amabilino, WileyVCH, Weinheim, 2009, pp. 271-304.

4 H. Takezoe, Top. Curr. Chem., 2012, 318, 303-330.

5 C. Tschierske, Angew. Chem., Int. Ed., 2013, 52, 8828-8878.

6 C. Tschierske and G. Ungar, ChemPhysChem, 2016, 17, 9-26.

7 K.-U. Jeong, B. S. Knapp, J. J. Ge, S. Jin, M. J. Graham, F. W. Harris and S. Z. D. Cheng, Chem. Mater., 2006, 18, 680-690.

8 C. Roche, H.-J. Sun, M. E. Prendergast, P. Leowanawat, B. E. Partridge, P. A. Heiney, F. Araoka, R. Graf, H. W. Spiess, X. B. Zeng, G. Ungar and V. Percec, J. Am. Chem. Soc., 2014, 136, 7169-7185.

9 (a) V. P. Panov, M. Nagaraj, J. K. Vij, Y. P. Panarin, A. Kohlmeier, M. G. Tamba, R. A. Lewis and G. H. Mehl, Phys. Rev. Lett., 2010, 105, 167801; (b) V. Borshch, Y.-K. Kim, J. Xiang, M. Gao, A. Jakli, V. P. Panov, J. K. Vij, C. T. Imrie, M. G. Tamba, G. H. Mehl and O. D. Lavrentovich, Nat. Commun., 2013, 4, 2635.

10 M. Cestari, S. Diez-Berart, D. A. Dunmur, A. Ferrarini, M. R. de la Fuente, D. J. B. Jackson, D. O. Lopez, G. R. Luckhurst, M. A. Perez-Jubindo, R. M. Richardson, J. Salud, B. A. Timimi and H. Zimmermann, Phys. Rev. E, 2011, 84, 031704. 
11 D. Chen, J. H. Porada, J. B. Hooper, A. Klittnick, Y. Shen, M. R. Tuchband, E. Korblova, D. Bedrov, D. M. Walba, M. A. Glaser, J. E. Maclennan and N. A. Clark, Proc. Natl. Acad. Sci. U. S. A., 2013, 110, 15931-15936.

12 S.-W. Choi, T. Izumi, Y. Hoshino, Y. Takanishi, K. Ishikawa, J. Watanabe and H. Takezoe, Angew. Chem., Int. Ed., 2006, 45, 1382-1385.

13 H. -S. Kitzerow and C. Bahr, Chirality in Liquid Crystals, Springer-Verlag, New York, 2001.

14 A. Belaissaoui, S. J. Kowling and J. W. Goodby, Liq. Cryst., 2013, 40, 822-830.

15 D. Chen, H. Wang, M. Li, M. A. Glaser, J. E. Maclennan and N. A. Clark, Soft Matter, 2014, 10, 9105-9109.

16 L. E. Hough, M. Spannuth, M. Nakata, D. A. Coleman, C. D. Jones, G. Dantlgraber, C. Tschierske, J. Watanabe, E. Körblova, D. M. Walba, J. E. Maclennan, M. A. Glaser and N. A. Clark, Science, 2009, 325, 452-456.

17 L. E. Hough, H. T. Jung, D. Krüerke, M. S. Heberling, M. Nakata, C. D. Jones, D. Chen, D. R. Link, J. Zasadzinski, G. Heppke, J. P. Rabe, W. Stocker, E. Körblova, D. M. Walba, M. A. Glaser and N. A. Clark, Science, 2009, 325, 456-460.

18 D. Chen, R. Shao, J. E. Maclennan, M. A. Glaser, E. Körblova, D. M. Walba, N. Gimeno, M. B. Ros and N. A. Clark, Liq. Cryst., 2013, 40, 1730-1735.

19 (a) I. Dierking, Angew. Chem., Int. Ed., 2010, 49, 29-30; (b) J. P. F. Lagerwall and F. Giesselmann, ChemPhysChem, 2010, 11, 975-977.

20 V. Görtz, Liq. Cryst. Today, 2010, 19, 37-48.

21 (a) M. Alaasar, M. Prehm, M. Nagaraj, J. K. Vij and C. Tschierske, Adv. Mater., 2013, 25, 2186-2191; (b) M. Alaasar, M. Prehm, K. May, A. Eremin and C. Tschierske, Adv. Funct. Mater., 2014, 24, 1703-1717.

22 C. Dressel, F. Liu, M. Prehm, X.-B. Zeng, G. Ungar and C. Tschierske, Angew. Chem., Int. Ed., 2014, 53, 13115-13120.

23 C. Dressel, T. Reppe, M. Prehm, M. Brautzsch and C. Tschierske, Nat. Chem., 2014, 6, 971-977.

24 M. Alaasar, M. Prehm, Y. Cao, F. Liu and C. Tschierske, Angew. Chem., Int. Ed., 2016, 55, 312-316.

25 A. Yoshizawa, Y. Kato, H. Sasaki, Y. Takanishi and J. Yamamoto, J. Phys. Chem. B, 2016, 120, 4843-4851.

26 (a) G. Dantlgraber, A. Eremin, S. Diele, A. Hauser, H. Kresse, G. Pelzl and C. Tschierske, Angew. Chem., Int. Ed., 2002, 41, 2408-2414; (b) C. Keith, R. A. Reddy, A. Hauser, U. Baumeister and C. Tschierske, J. Am. Chem. Soc., 2006, 128, 3051-3066.

27 G. Heppke, D. D. Parghi and H. Sawade, Liq. Cryst., 2000, 27, 313-320.

28 J. Thisayukta, Y. Nakayama, S. Kawauchi, H. Takezoe and J. Watanabe, J. Am. Chem. Soc., 2000, 122, 7441-7448.

29 R. A. Reddy and B. K. Sadashiva, Liq. Cryst., 2003, 30, 10311050.

30 A. Roy, M. Gupta, S. Radhika, B. K. Sadashiva and R. Pratibha, Soft Matter, 2012, 8, 7207-7214.

31 J. Ortega, C. L. Folcia, J. Etxebarria, N. Gimeno and M. B. Ros, Phys. Rev. E: Stat., Nonlinear, Soft Matter Phys., 2003, 68, 11707.
32 S. Kang, Y. Saito, N. Watanabe, M. Tokita, Y. Takanishi, H. Takezoe and J. Watanabe, J. Chem. Phys. B, 2006, 110, 5205-5214.

33 (a) M. Nagaraj, K. Usami, Z. Zhang, V. Görtz, J. W. Goodby and H. F. Gleeson, Liq. Cryst., 2014, 41, 800-811; (b) M. Nagaraj, J. C. Jones, V. P. Panov, H. Liu, G. Portale, W. Bras and H. F. Gleeson, Phys. Rev. E, 2015, 91, 042504.

34 (a) S. K. Lee, X. Li, S. Kang, M. Tokitra and J. Watanabe, J. Mater. Chem., 2009, 19, 4517-4522; (b) T. Bao, K. Wang and M.-S. Zhan, Liq. Cryst., 2014, 41, 1687-1695.

35 (a) A. Jákli, Y.-M. Huang, K. Fodor-Csorba, A. Vajda, G. Galli, S. Diele and G. Pelzl, Adv. Mater., 2003, 15, 1606-1610; (b) W. Weissflog, M. W. Schröder, S. Diele and G. Pelzl, Adv. Mater., 2003, 15, 630-633.

36 (a) S. K. Lee, L. Shi, M. Tokita, H. Takezoe and J. Watanabe, J. Phys. Chem. B, 2007, 111, 8698-8701; (b) S. K. Lee, L. Shi, M. Tokita and J. Watanabe, J. Phys. Chem. B, 2008, 112, 6762-6766.

37 (a) D. M. Walba, L. Eshat, E. Körblova and R. K. Shoemaker, Cryst. Growth Des., 2005, 5, 2091-2099; (b) D. Chen, J. E. Maclennan, R. Shao, D. K. Yoon, H. Wang, E. Körblova, D. M. Walba, M. A. Glaser and N. A. Clark, J. Am. Chem. Soc., 2011, 133, 12656-12663.

38 J. M. -Perdiguero, I. Alonso, C. L. Folcia, J. Etxebarria and J. Ortega, J. Mater. Chem., 2009, 19, 5161-5166.

39 C. Zhang, N. Diorio, O. D. Lavrentovich and A. Jákli, Nat. Commun., 2014, 5, 3302.

40 (a) J. Thisayukta, H. Takezoe and J. Watanabe, Jpn. J. Appl. Phys., Part 1, 2001, 40, 3277; (b) H. Niwano, M. Nakata, J. Thisayukta, D. R. Link, H. Takezoe and J. Watanabe, J. Phys. Chem. B, 2004, 108, 14889-14896; (c) H. Kurosu, M. Kawasaki, M. Hirose, M. Yamada, S. Kang, J. Thisayukta, M. Sone, H. Takezoe and J. Watanabe, J. Phys. Chem. A, 2004, 108, 4674-4678.

41 H. Kresse, J. Saltetnokova, H. Nadasi, W. Weissflog and A. Hauser, Liq. Cryst., 2001, 28, 1017-1023.

42 (a) E. Bialecka-Florjanczyk, I. Sledzinska, E. Górecka and J. Przedmojski, Liq. Cryst., 2008, 35, 401-406; (b) A. Zep, M. Salamonczyk, N. Vaupotič, D. Pociecha and E. Gorecka, Chem. Commun., 2013, 49, 3119-3121.

43 T. Niori, T. Sekine, J. Watanabe, T. Furukawa and H. Takezoe, J. Mater. Chem., 1996, 6, 1231-1233.

44 C. Zhu, C. Wang, A. Young, F. Liu, I. Gunkel, D. Chen, D. Walba, J. Maclennan, N. Clark and A. Hexemer, Nano Lett., 2015, 15, 3420-3424.

45 M. Alaasar, M. Prehm and C. Tschierske, Chem. Commun., 2013, 49, 11062-11064.

46 M. Alaasar, M. Prehm, M. Brautzsch and C. Tschierske, J. Mater. Chem. C, 2014, 2, 5487-5501.

47 M. Alaasar, M. Prehm, M. Brautzsch and C. Tschierske, Soft Matter, 2014, 10, 7285-7296.

48 M. Alaasar, M. Prehm and C. Tschierske, Chem.-Eur. J., 2016, 22, 6583-6597.

49 M. Alaasar, M. Prehm and C. Tschierske, Liq. Cryst., 2013, 40, 656-668.

50 For a comparison of chlorine and bromine substituted BCLCs with phenylbenzoate wings, see: (a) W. Weissflog, 
S. Sokolowski, H. Dehne, B. Das, S. Grande, M. W. Schröder, A. Eremin, S. Diele, G. Pelzl and H. Kresse, Liq. Cryst., 2004, 31, 923-933; (b) S. Kang, J. Thisayukta, H. Takezoe, J. Watanabe, K. Ogino, T. Doi and T. Takahashi, Liq. Cryst., 2004, 31, 1323-1336.

51 M. Alaasar, M. Prehm, M.-G. Tamba, N. Sebastian, A. Eremin and C. Tschierske, ChemPhysChem, 2016, 17, 278-287.

52 K. Miyasato, S. Abe, H. Takezoe, A. Fukuda and E. Kuze, Jpn. J. Appl. Phys., Part 1, 1983, 22, L661-L663.

53 (a) T. Otani, F. Araoka, K. Ishikawa and H. Takezoe, J. Am. Chem. Soc., 2009, 131, 12368; (b) F. Araoka, G. Sugiyama, K. Ishikawa and H. Takezoe, Opt. Mater. Express, 2011, 1, 27. 54 K. Gomola, L. Guo, D. Pociecha, F. Araoka, K. Ishikawa and H. Takezoe, J. Mater. Chem., 2010, 20, 7944-7952.
55 Y. Shimbo, E. Gorecka, D. Pociecha, F. Araoka, M. Goto, Y. Takanishi, K. Ishikawa, J. Mieczkowski, K. Gomola and H. Takezoe, Phys. Rev. Lett., 2006, 97, 113901.

56 A. Immirzi and B. Perini, Acta Crystallogr., Sect. A: Cryst. Phys., Diffr., Theor. Gen. Crystallogr., 1977, 33, 216-218.

57 A. J. Kirby, The anomeric effect and related stereoelectronic effects at oxygen, Springer, Berlin, Heidelberg, 1983.

58 (a) T. Steiner and G. R. Desiraju, Chem. Commun., 1998, 8, 891-892; (b) O. Takahashi, Y. Kohno and M. Nishio, Chem. Rev., 2010, 110, 6049-6076.

59 M. F. Achard, J. P. Bedel, J. P. Marcerou, H. T. Nguyen and J. C. Rouillon, Eur. Phys. J. E, 2003, 10, 129-134. 